\title{
The effects of BAFF on T lymphocytes in chronic obstructive pulmonary disease
}

\author{
Shupei Gao, Jinqing Chen, Jungang Xie and Jianmiao Wang*
}

\begin{abstract}
Background: It has been reported that B cell activating factor belonging to the tumor necrosis factor family (BAFF) expression is increased in chronic obstructive pulmonary disease (COPD). However its role in this chronic inflammatory disease is not fully understood. Previous studies have suggested that BAFF also affects T cell function. We therefore investigated the effects of BAFF on T lymphocytes in COPD.

Methods: BAFF was detected in the cells of sputum and the plasma. Peripheral blood mononuclear cells (PBMCs) were isolated from COPD patients and treated with BAFF or BAFF plus BR3-FC (BAFF antagonist). The apoptosis of $\mathrm{CD}^{+}$cells and $\mathrm{CD} 8^{+}$cells was analyzed by flow cytometry. $\mathrm{CD} 4^{+}$cells and $\mathrm{CD} 8^{+}$cells were isolated from peripheral blood of COPD patients respectively and treated with BAFF or BAFF plus BR3-Fc. Interferon- $\gamma$ (IFN- $\gamma$ ) and interleukin4 (IL-4) were detected in the $\mathrm{CD}_{4}^{+}$cells, and perforin and granzyme B were detected in the $\mathrm{CD}^{+}$cells.
\end{abstract}

Results: BAFF expression was increased in the cells of sputum and the plasma from COPD patients compared with control subjects. The plasma BAFF levels were inversely correlated with $\mathrm{FEV}_{1}$ percentage of predicted in patients with COPD. BAFF did not significantly alter the apoptosis of $\mathrm{CD}^{+}$cells, however it significantly inhibited the apoptosis of $\mathrm{CD}^{+}$cells from COPD patients. BAFF increased IFN- $\gamma$ expression in the CD4 $4^{+}$cells from COPD patients, while it did not significantly alter the expresson of IL-4 in these cells. BAFF increased the expression of perforin and granzyme $\mathrm{B}$ in the $\mathrm{CD} 8^{+}$cells from COPD patients.

Conclusions: Our findings indicate that BAFF may be involved in the inflammatory response in COPD via affecting T lymphocytes, suggesting a possible role of BAFF in the pathogenesis of COPD.

Keywords: B cell activating factor belonging to the tumor necrosis factor family (BAFF), Chronic obstructive pulmonary disease, Inflammation, T lymphocytes

\section{Background}

Chronic obstructive pulmonary disease (COPD) is a common disease characterized by persistent respiratory symptoms and airflow limitation, which is a leading cause of morbidity and mortality worldwide [1]. The prevalence and burden of COPD are projected to increase over the coming decades due to continued exposure to risk factors and aging of the world's population [2]. The lung inflammation caused by cigarette smoke or

* Correspondence: wangjianmiao2010@126.com

Department of Respiratory and Critical Care Medicine, Tongji Hospital, Tongji Medical College, Huazhong University of Science and Technology, 1095 Jiefang Road, Wuhan 430030, China other noxious particles induces tissue destruction and airway fibrosis, leading to the gas trapping and progressive airflow limitation [3].

The pathological changes observed in COPD include chronic inflammation and structural changes with increased numbers of specific inflammatory cell types in different parts of the lung [4]. Previous studies have shown that the number of pulmonary $\mathrm{CD}^{+} \mathrm{T}$ cells in COPD increases substantially with higher stages of airflow limitation, and reduced apoptosis of $\mathrm{CD}^{+}$cells may contribute to the accumulation of these cells in the lung [5]. $\mathrm{CD}^{+} \mathrm{T}$ cells release proteolytic enzymes such as perforin and granzymes, which cause cell death of structural cells by apoptosis or necrosis [6]. 
Numbers of $\mathrm{CD}^{+} \mathrm{T}$ helper 1 (Th1) cells are also raised in the airways and lungs of COPD, which produce interferon- $\gamma$ (IFN- $\gamma$ ) and promote accumulation of inflammatory cells to the lung. Lung lymphocytes in patients with COPD have higher percentages of $\mathrm{CD}_{4}^{+}$Th1 cells and secrete more IFN$\gamma$ than in control smokers [7]. These findings suggest that $\mathrm{T}$ lymphocytes including $\mathrm{CD}^{+}$and $\mathrm{CD} 4^{+} \mathrm{T}$ cells play an important role in the pathogenesis of COPD.

$\mathrm{B}$ cell activating factor belonging to the tumor necrosis factor family (BAFF) is an important cytokine for B cell survival and maturation [8], which is expressed by many cell types including macrophages, dendritic cells and epithelial cells [9]. It binds to three receptors on B cells including BAFF receptor (BR3), transmembrane activator and calcium modulator cyclophilin ligand interactor (TACI) and B cell maturation antigen (BCMA). Overexpression of BAFF is associated with autoimmune diseases in humans and mice $[10,11]$. It has been reported that BAFF expression is increased in the lung of patients with COPD, mainly in alveolar macrophages and lymphoid follicles, and BAFF-positive macrophages are inversely related to $\mathrm{FEV}_{1}$ in COPD [12]. Later studies have shown that recombinant BAFF blocks cigarette smoke extract induced B cell apoptosis and antagonizing BAFF in cigarette smoke exposed mice attenuates pulmonary inflammation and alveolar destruction [13, 14]. These findings suggest that BAFF might be associated with increasing lung function decline in COPD.

Previous studies have suggested that BAFF also affects T cell function through binding to the receptor BR3 and augments certain Th1 associated inflammatory responses $[15,16]$. However, it is not clear whether BAFF affects $\mathrm{T}$ lymphocytes in COPD. In the present study, we utilized in vitro experiments to investigate the effects of BAFF on $\mathrm{CD}^{+}$and $\mathrm{CD}^{+}$cells from the peripheral blood of COPD patients.

\section{Methods}

\section{Subjects}

COPD patients aged 40 to 80 years old were recruited from the out-patient department of Tongji Hospital, Tongji Medical College, Huazhong University of Science and Technology, Wuhan, China, between 2018 and 2019. All patients were diagnosed with COPD based on clinical history, physical examination, chest radiograph and spirometry according to the Global Initiative for Chronic Obstructive Lung Disease (GOLD) criteria [1]. Inclusion critiria are as follows: males aged between 40 to 80 years old with a history of at least 20 pack-years of smoking. Exclusion criteria are as follows: chronic respiratory diseases such as asthma, active tuberculosis, bronchiectasis and interstitial lung disease; cardiac, hepatic or renal failure; malignant diseases; autoimmune diseases; and current oral steroid therapy. All COPD patients were examined in stable condition. Nonsmokers without COPD and smokers without COPD were recruited from the health screening center of our hospital as control subjects. The exclusion criteria mentioned above were also used to screen the control subjects. The study was approved by the hospital ethics committees, and all subjects gave written informed consent.

\section{Pulmonary function tests}

Forced vital capacity and forced expiratory volume in the first second $\left(\mathrm{FEV}_{1}\right)$ were obtained from the flow-volume curve using an appropriately calibrated spirometer (Jaeger, Wurzburg, Germany) before and 20 min after salbutamol inhalation. Three technically acceptable measurements were performed on each patient, and the highest value was selected and expressed as a percentage of reference values. The predicted $F E V_{1}$ was calculated using the following prediction equations recommended by the American Thoracic Society/ European Respiratory Society Task Force 2005 [17] (Predicted $\mathrm{FEV}_{1}=4.30 \times$ height in meters- $0.029 \times$ age-2.49).

\section{Sample collection}

Sputum and heparinized peripheral venous blood samples were collected from nonsmokers, smokers and COPD patients. Sputum induction with hypertonic saline was performed as previously described [18]. Sputum plugs were separated from sputum, and dithiothreitol was used to disperse mucus. Cytospin preparations for immunocytochemistry were made with centrifugation at $980 \mathrm{rpm}$ for 8 mintues. Plasma was separated from fresh heparinized blood, and the blood cells were used for peripheral blood mononuclear cell (PBMC), $\mathrm{CD} 4^{+}$cells or $\mathrm{CD} 8^{+}$cells isolation.

\section{Immunocytochemistry}

Slides were washed with phosphate buffered saline (PBS) and incubated with $3 \% \mathrm{H}_{2} \mathrm{O}_{2}$ for $10 \mathrm{~min}$. After incubation with $5 \%$ bovine serum albumin (BSA) for $45 \mathrm{~min}$, BAFF was localized using the rabbit polyclonal anti-BAFF antibody (Abcam, Cambridge, MA, USA). The bound antibodies were detected with horseradish peroxidase (HRP)-conjugated secondary antibody (Gene Tech, Shanghai, China), then 3amino-9-ethylcarbazole (Boster, Wuhan, China) was added for the detection and haematoxylin (Boster, Wuhan, China) was used for the nucleus counterstain.

\section{Enzyme-linked immunosorbent assay}

The BAFF protein levels in plasma were determinated using enzyme-linked immunosorbent assay (ELISA) kits (R\&D Systems, Minneapolis, MN, USA) according to the manufacturer's instructions. The protein levels of IFN- $\gamma$ and IL- 4 in the supernatant of $\mathrm{CD} 4^{+}$cells culture were detected using ELISA kits (R\&D Systems, Minneapolis, $\mathrm{MN}$, USA) according to the manufacturer's instructions. 


\section{Cells isolation}

PBMCs were isolated from heparinized peripheral venous blood of COPD patients using density centrifugation. Briefly, the fresh peripheral blood was centrifugated at $1500 \mathrm{rpm}$ for $10 \mathrm{~min}$, then the supernatant containing leukocytes was mixed with PBS, and was carefully layered onto Ficoll-Hypaque gradient (Dakewe Biotech, Shenzhen, China). PBMCs layer was obtained after centrifugation, cells were washed and resuspended for cell culture or for $\mathrm{CD} 4^{+}$or $\mathrm{CD}^{+}$cells isolation. $\mathrm{CD} 4^{+}$and $\mathrm{CD}^{+}$cells of COPD patients were separated from the PBMCs using MagCellect Human $\mathrm{CD} 4^{+} / \mathrm{CD}^{+}{ }^{+} \mathrm{T}$ Cell Isolation Kits (R\&D Systems, Minneapolis, MN, USA) according to the manufacturer's instructions.

\section{Cell culture}

The isolated PBMCs were washed with pre-cold PBS and cultured with supplemented RPMI 1640 medium in 24-well plates. Cells were stimulated with rhBAFF $(20 \mathrm{ng} / \mathrm{ml}, \mathrm{R} \& D$ Systems, Minneapolis, MN, USA) or a combination of rhBAFF and BR3-Fc $(100 \mu \mathrm{g} / \mathrm{ml}, \mathrm{R} \& D$ Systems, Minneapolis, MN, USA) at $37^{\circ} \mathrm{C}$ with $5 \% \mathrm{CO}_{2}$ for $48 \mathrm{~h}$. Cells were harvested for assessment of apoptosis of $\mathrm{CD} 4^{+}$and $\mathrm{CD} 8^{+}$cells using flow cytometry. Isolated $\mathrm{CD} 4^{+}$or $\mathrm{CD}^{+}$cells were cultured with supplemented RPMI 1640 medium and phytohemagglutinin (Sigma-Aldrich and Merck KGaA, Darmstadt, Germany) in 24-well plates. Cells were stimulated with rhBAFF or a combination of rhBAFF and BR3-Fc at $37^{\circ} \mathrm{C}$ with $5 \% \mathrm{CO}_{2}$ for $72 \mathrm{~h}$. For $\mathrm{CD}^{+}$cells culture, the supernatant and cells were seperately obtained for the detection of IL-4 and IFN- $\gamma$ expression. For $\mathrm{CD}^{+}$cells culture, the cells were harvested for the detection of mRNA expression of perforin and granzyme $B$.

\section{Flow cytometry}

PBMCs were harvested for detection of apoptosis of $\mathrm{CD} 4^{+}$ and $\mathrm{CD}^{+}$cells using flow cytometry. Briefly, after blocking, cells were incubated on ice with FITC-conjugated anti-CD4 antibody (Biolegend, San Diego, CA, USA) and PEconjugated anti-CD8 antibody (Biolegend, San Diego, CA, USA) for $30 \mathrm{~min}$ in the dark. The cells were washed and incubated with APC-conjugated annexin V (Biolegend, San Diego, CA, USA) for $15 \mathrm{~min}$ in the dark and were analyzed.

\section{Quantitative polymerase chain reaction}

Total RNA was isolated from the $\mathrm{CD}^{+}$cells and $\mathrm{CD} 8^{+}$cells and was reverse-transcribed into cDNA using PrimeScript RT Reagent Kit (Takara, Shiga, Japan). Quantitative polymerase chain reaction (PCR) was performed using a Bio-Rad CFX Connect Real-Time System (Bio-Rad, Hercules, CA, USA) with SYBR Premix Ex Taq (Takara, Shiga, Japan) and the specific primers. The primer sequences were as follows: $\beta$-actin (forward, GCAAGCAGGACTATGACGAG and reverse, CAAATAAAGCCATGCCAATC),
IFN- $\gamma$ (forward, TTCTTACAACACAAAATCAAAT CA and reverse, TCAACAAAGCTGATACTCCA), IL4 (forward, ATGGGTCTCACCTCCCAACT and reverse, GATGTCTGTTACGGTCAACTCG), perforin (forward, CCCAGTGGACACACAAAGGTT and reverse, TCGTTGCGGATGCTACGAG), granzyme B (forward, CCCTGGGAAAACACTCACACA and reverse, CACAACTCAATGGTACTGTCGT). The relative mRNA expression was determined using the $2^{-\Delta \Delta \mathrm{Ct}}$ methods with $\beta$-actin as endogenous control.

\section{Statistical analysis}

Results were expressed as mean \pm SEM unless otherwise specified. D'Agostino and Pearson omnibus normality test was used to determine whether the data were normally distributed. Data that were normally distributed were assessed for significance by Student's t-test or ANOVA as appropriate. Data that were not normally distributed were assessed for significance using the Mann-Whitney U-test or the Kruskal-Wallis test with Dunn's posttest for multiple comparisons as appropriate. The correlations were analyzed by Pearson's correlation. Statistical analysis was performed using Prism version 6 (GraphPad). A two-sided $p$-value $<0.05$ was considered to be statistically significant.

\section{Results}

\section{Characteristics of subjects}

The characteristics of subjects are shown in Table 1. Totally, 94 subjects were recruited to the study including 16 nonsmokers without COPD, 36 smokers without COPD and 42 COPD patients. All of them were male, and there were no significant differences in age and body mass index among the three groups. There was no significant difference in smoking index between the smokers and the patients with COPD. $\mathrm{FEV}_{1}$ \%predicted ( $\mathrm{FEV}_{1} \%$ pred),

Table 1 Clinical characteristics of subjects in this study

\begin{tabular}{llll}
\hline & Nonsmoker & Smoker & COPD \\
\hline Subjects & 16 & 36 & 42 \\
Age yrs & $58.6 \pm 2.2$ & $60.2 \pm 1.1$ & $63.7 \pm 1.2$ \\
Male & $16(100 \%)$ & $36(100 \%)$ & $42(100 \%)$ \\
Smoking index p.y & 0 & $47.8 \pm 4.3$ & $48.6 \pm 4.0$ \\
BMl kg/m ${ }^{2}$ & $23.1 \pm 0.5$ & $23.0 \pm 0.3$ & $22.1 \pm 0.3$ \\
FVC \% pred & $108.3 \pm 3.5$ & $114.2 \pm 2.5$ & $90.6 \pm 2.8^{* *}$ \\
FEV 1 /FVC\% & $81.0 \pm 1.3$ & $77.3 \pm 1.0$ & $52.0 \pm 2.0^{* *}$ \\
FEV $\%$ pred & $109.7 \pm 3.2$ & $109.2 \pm 2.6$ & $61.1 \pm 3.5^{* *}$ \\
\hline
\end{tabular}

Values are numbers (\%) or mean \pm SEM; COPD Chronic Obstructive Pulmonary Disease, p.y pack-yrs, BMI body mass index, FVC forced vital capacity, FEV forced expiratory volume in $1 \mathrm{sec}, \%$ pred $\%$ predicted; **: $P<0.01$ versus nonsmoker and smoker 


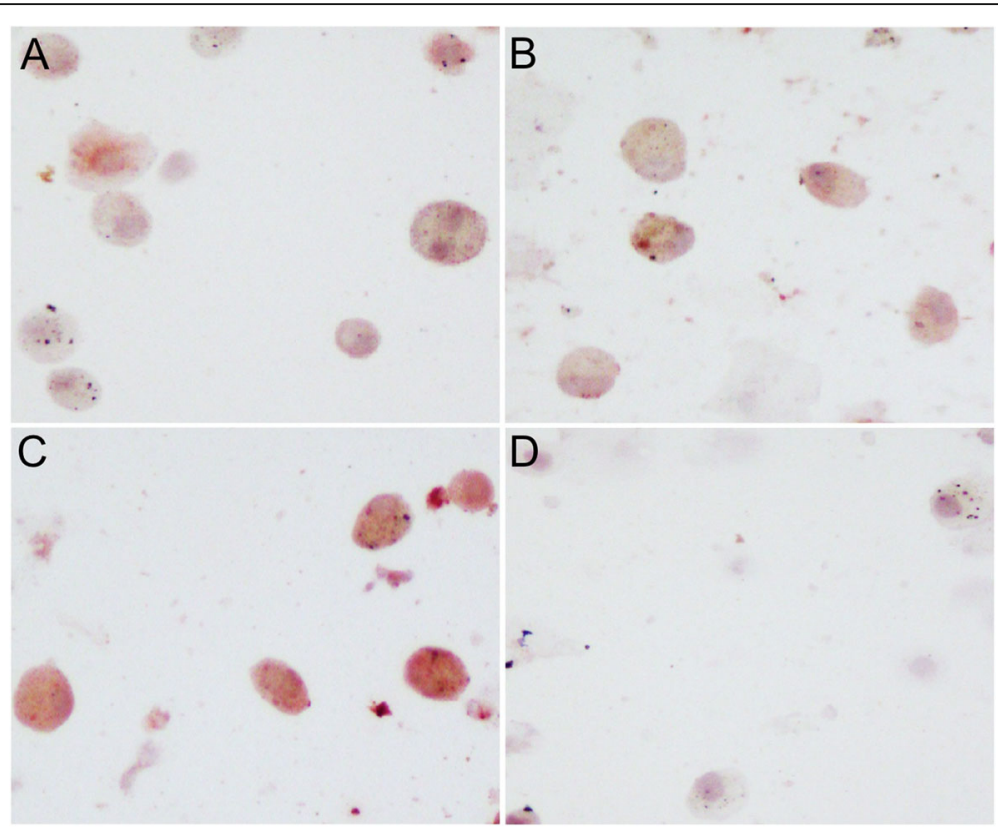

Fig. 1 B cell activating factor (BAFF) expression in the cells of sputum from the subjects. The representative immunocytochemistry images of BAFF staining in the cells of sputum from a nonsmoker without COPD (a), a smoker without COPD (b) and a COPD patient (c) are shown, and the negative control is also shown (d). Original magnification, $\times 200$

$\mathrm{FEV}_{1} /$ forced vital capacity (FVC) and FVC\%pred were significantly lower in patients with COPD than those in the smokers and nonsmokers.

\section{BAFF expression in the cells of sputum}

To investigate BAFF expression in the cells of sputum from nonsmokers, smokers and COPD patients, sputum samples were obtained and BAFF expression was detected using immunocytochemistry. The representative results were shown in Fig. 1. The expression of BAFF in the cells (mainly macrophages) of sputum from COPD patients was increased compared with smokers and nonsmokers.

\section{BAFF expression in the plasma}

To assess BAFF expression in the palsma of COPD patients, peripheral venous blood samples from nonsmokers, smokers and patients with COPD were obtained and ELISA was performed. BAFF expression in plasma was significantly increased in COPD patients
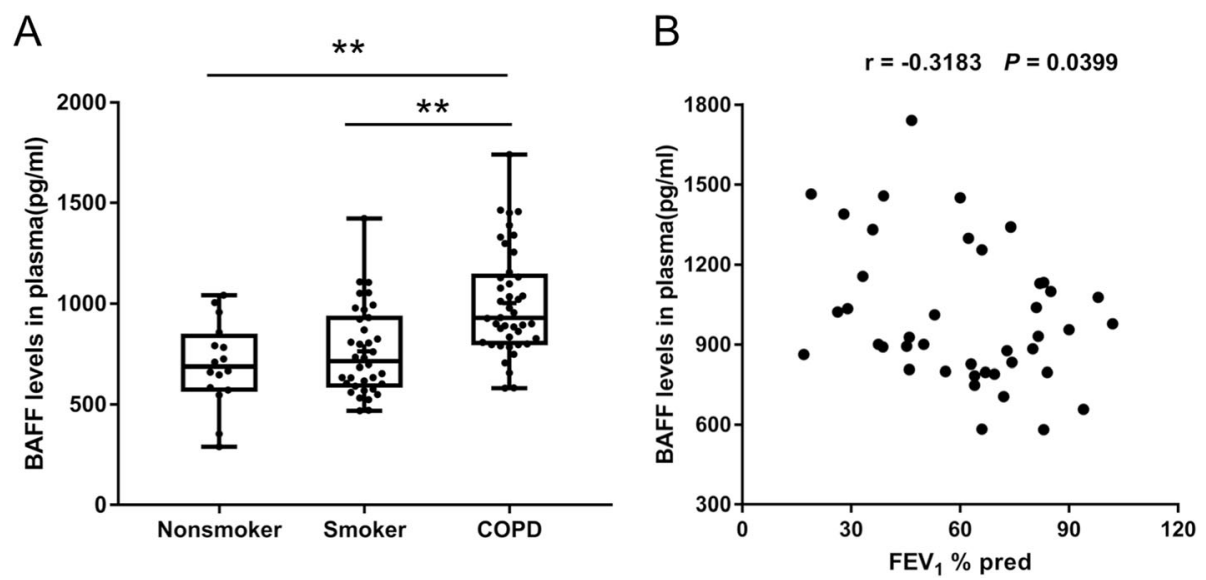

Fig. 2 B cell activating factor (BAFF) expression in the plasma from the subjects. The expression levels of BAFF in the plasma from nonsmokers without COPD $(n=16)$, smokers without COPD $(n=36)$ and COPD patients $(n=42)$ are shown $(\mathbf{a})$. The data are presented as median (P25 quartile, P75 quartile). The correlation between the plasma BAFF expression levels and forced expiratory volume in 1 sec (FEV $\left.V_{1}\right) \%$ predicted in COPD patients $(n=42)$ is shown $(\mathbf{b}) .{ }^{*} P<0.01$ 
Table 2 Characteristics of patients for PBMCs isolation and stimulation

\begin{tabular}{llllll}
\hline Patient number & Sex & $\begin{array}{l}\text { Age } \\
\text { yrs. }\end{array}$ & $\begin{array}{l}\mathrm{BMl} \\
\mathrm{kg} / \mathrm{m}^{2}\end{array}$ & $\begin{array}{l}\text { Smoking index } \\
\text { p.y }\end{array}$ & $\mathrm{FEV}_{1} \%$ pred \\
\hline 1 & male & 64 & 25.0 & 50 & 46.7 \\
2 & male & 68 & 18.5 & 150 & 33.2 \\
3 & male & 72 & 21.3 & 30 & 46.0 \\
4 & male & 59 & 22.6 & 20 & 63.0 \\
5 & male & 54 & 24.5 & 20 & 50.0 \\
6 & male & 55 & 26.7 & 37 & 67.0 \\
7 & male & 72 & 22.9 & 30 & 40.6 \\
8 & male & 64 & 24.2 & 80 & 22.0 \\
9 & male & 74 & 23.5 & 50 & 74.3 \\
10 & male & 69 & 23.7 & 40 & 33.9 \\
11 & male & 72 & 22.2 & 60 & 64.2 \\
12 & male & 71 & 21.1 & 45 & 26.3 \\
13 & male & 57 & 25.6 & 20 & 36.9 \\
\hline
\end{tabular}

PBMCs peripheral blood mononuclear cells, $B M I$ body mass index ,p.y pack-yrs, $F E V_{1}$ forced expiratory volume in $1 \mathrm{sec}$ \% \%red \%predicted compared with nonsmokers and smokers (Fig. 2a). We also analyzed the association between plasma BAFF expression and pulmonary function, and found that plasma BAFF levels were significantly correlated with $\mathrm{FEV}_{1}$ \%pred in patients with COPD (Fig. 2b).

\section{Effects of BAFF on the apoptosis of $\mathrm{CD}^{+}$cells}

To investigate the effects of BAFF on the apoptosis of $\mathrm{CD}^{+}$lymphocytes in COPD, PBMCs from 13 COPD patients were cultured and treated with rhBAFF or a combination of rhBAFF and BR3-Fc (BAFF antagonist). The characteristics of 13 COPD patients are shown in Table 2 . The apoptosis of $\mathrm{CD}_{4}^{+}$cells was analyzed using flow cytometry. The gating strategy was shown in Fig. 3a and b. We found that BAFF did not significantly alter the apoptosis of $\mathrm{CD}^{+}$cells in COPD (Fig. 3c, d, e and f).

\section{Effects of BAFF on the apoptosis of $\mathrm{CD}^{+}$cells}

To investigate the effects of BAFF on the apoptosis of $\mathrm{CD}^{+}$lymphocytes in COPD, PBMCs from 13 COPD patients were cultured and treated with rhBAFF or a combination of rhBAFF and BR3-Fc. The characteristics of these 13 COPD patients are

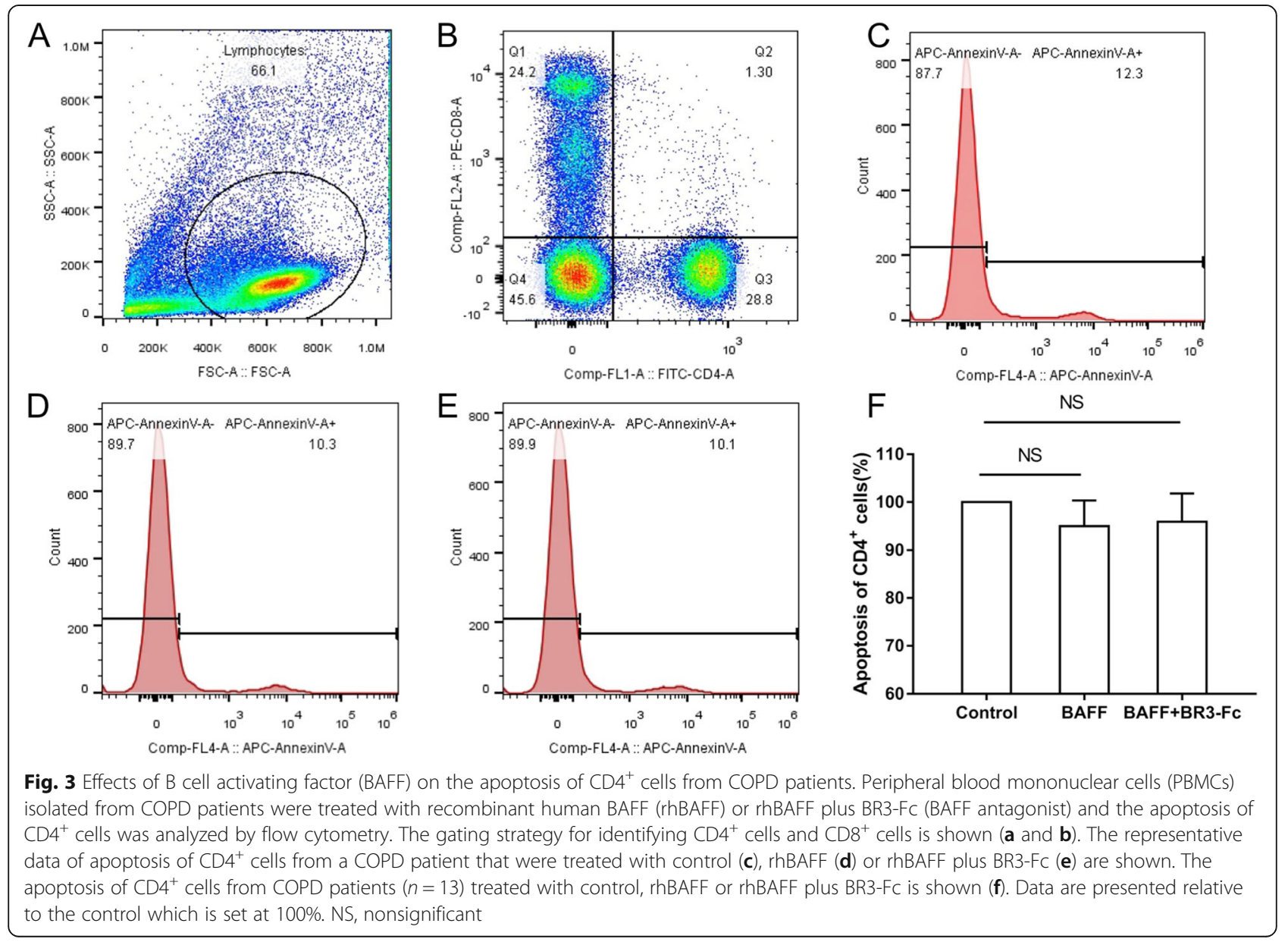



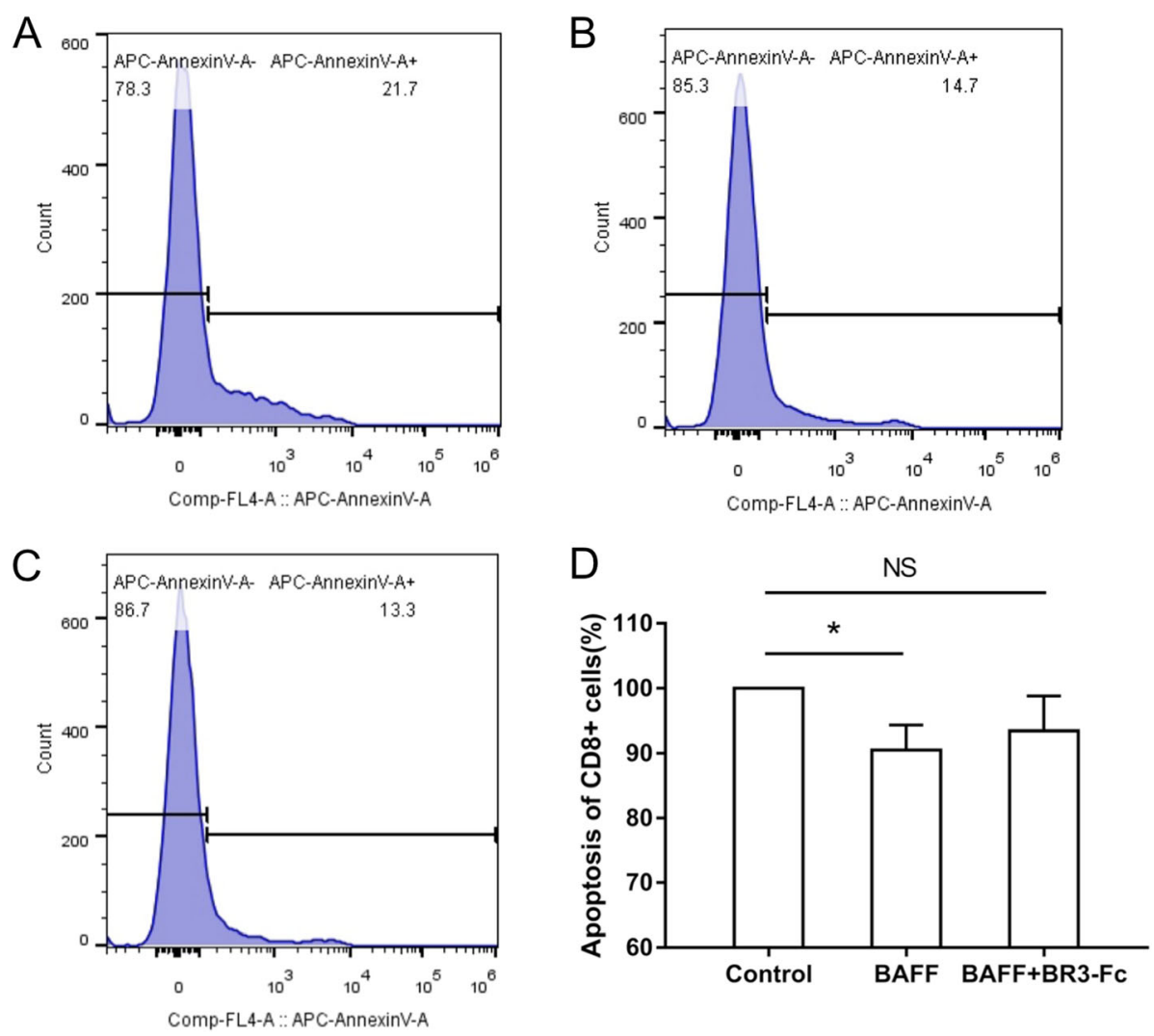

Fig. 4 Effects of B cell activating factor (BAFF) on the apoptosis of CD8 ${ }^{+}$cells from COPD patients. Peripheral blood mononuclear cells (PBMCs) isolated from COPD patients were treated with recombinant human BAFF (rhBAFF) or rhBAFF plus BR3-Fc (BAFF antagonist) and the apoptosis of $\mathrm{CD}^{+}$cells was analyzed by flow cytometry. The representative data of apoptosis of $\mathrm{CD} 8^{+}$cells from a COPD patient that were treated with control (a), rhBAFF (b) or rhBAFF plus BR3-Fc (c) are shown. The apoptosis of CD8 ${ }^{+}$cells from COPD patients $(n=13)$ treated with control, rhBAFF or rhBAFF plus BR3-Fc is shown (d). Data are presented relative to the control which is set at $100 \%{ }^{*} P<0.05$. NS, nonsignificant

Table 3 Characteristics of patients for $\mathrm{CD}^{+}$cells isolation and stimulation

\begin{tabular}{llllll}
\hline Patient number & Sex & $\begin{array}{l}\text { Age } \\
\text { yrs. }\end{array}$ & $\begin{array}{l}\mathrm{BMl} \\
\mathrm{kg} / \mathrm{m}^{2}\end{array}$ & $\begin{array}{l}\text { Smoking index } \\
\text { p.y }\end{array}$ & $\mathrm{FEV}_{1} \%$ pred \\
\hline 1 & male & 72 & 22.9 & 30 & 40.6 \\
2 & male & 64 & 24.2 & 80 & 22.0 \\
3 & male & 74 & 23.5 & 50 & 74.3 \\
4 & male & 69 & 23.7 & 40 & 33.9 \\
5 & male & 72 & 22.2 & 60 & 64.2 \\
6 & male & 71 & 21.1 & 45 & 26.3 \\
7 & male & 57 & 25.6 & 20 & 36.9 \\
8 & male & 64 & 16.7 & 30 & 16.1 \\
9 & male & 48 & 22.5 & 30 & 60.3 \\
10 & male & 66 & 28.0 & 40 & 25.0 \\
11 & male & 67 & 19.3 & 40 & 45.0 \\
12 & male & 54 & 26.3 & 80 & 33.8 \\
\hline
\end{tabular}

$B M I$ body mass index, p.y pack-yrs, $F E V$, forced expiratory volume in $1 \mathrm{sec}$, \%pred \%predicted shown in Table 2. The apoptosis of $\mathrm{CD} 8^{+}$cells was analyzed using flow cytometry. We found that BAFF significantly inhibited the apoptosis of $\mathrm{CD}^{+}$cells in COPD (Fig. 4).

\section{Effects of BAFF on cytokine expression of $\mathrm{CD}^{+}$cells}

To study the effects of BAFF on the cytokine expression of $\mathrm{CD} 4^{+}$cells including IFN- $\gamma$ and IL- $4, \mathrm{CD} 4^{+}$cells were isolated from the PBMCs of 12 COPD patients and cultured. The characteristics of these 12 COPD patients are shown in Table $3 . \mathrm{CD} 4^{+}$cells were treated with rhBAFF or a combination of rhBAFF and BR3-Fc. The mRNA levels of IFN- $\gamma$ and IL-4 in the cells and their protein levels in the supernatant were detected. We found that the mRNA levels of IFN- $\gamma$ in the $\mathrm{CD}_{4}^{+}$cells were increased significantly after BAFF treatment (Fig. 5a), while BAFF did not significantly alter the mRNA levels of IL-4 (Fig. 5b). The protein levels of IFN- $\gamma$ in the supernatant were also increased significantly after BAFF treatment (Fig. 5c), while BAFF did not significantly alter the protein levels of IL-4 in the supernatant (Fig. 5d). 

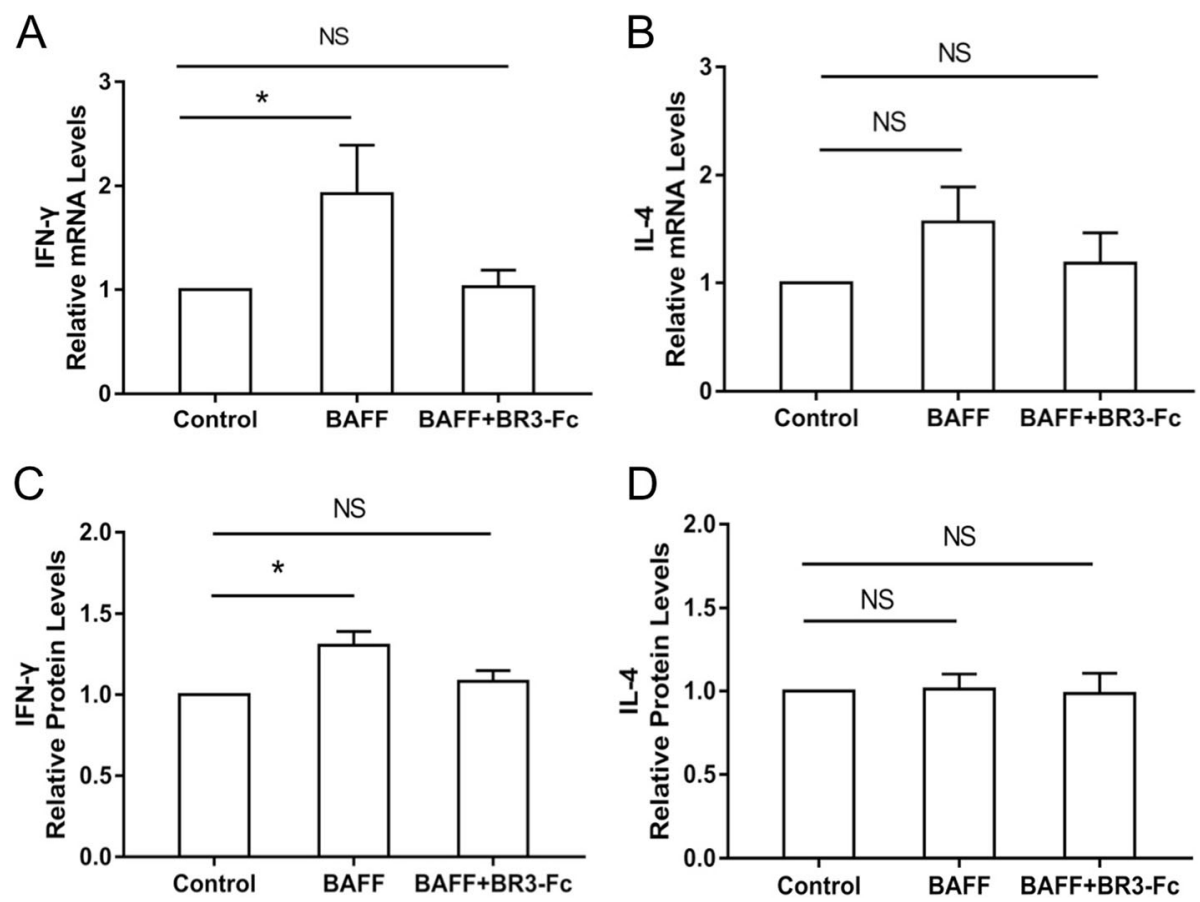

Fig. 5 Effects of B cell activating factor (BAFF) on cytokine expression of $C D 4^{+}$cells from COPD patients. CD4 ${ }^{+}$cells isolated from COPD patients were treated with control, recombinant human BAFF (rhBAFF) or rhBAFF plus BR3-Fc (BAFF antagonist) and the expression levels of interferon- $\gamma$ $($ IFN- $\gamma)$ and interleukin-4 (IL-4) were detected. The relative mRNA levels of IFN- $\gamma(\mathbf{a})$ and IL-4 (b) in the CD4 $4^{+}$cells from COPD patients $(n=12)$ are shown. The relative protein levels of IFN- $\gamma(\mathbf{c})$ and IL-4 (d) in the supernatant of CD4 ${ }^{+}$cells from COPD patients $(n=12)$ are shown. ${ }^{*} P<0.05$. NS, nonsignificant

\section{Effects of BAFF on perforin and granzyme B expression of CD8 ${ }^{+}$cells}

To study the effects of BAFF on the perforin and granzyme $\mathrm{B}$ expression of $\mathrm{CD}^{+}$cells, $\mathrm{CD}^{+}$cells were isolated from the PBMCs of 10 COPD patients and cultured. The characteristics of these 10 COPD patients are shown in Table $4 . \mathrm{CD}^{+}$cells were treated with

Table 4 Characteristics of patients for $\mathrm{CD}^{+}$cells isolation and stimulation

\begin{tabular}{llllll}
\hline Patient number & Sex & $\begin{array}{l}\text { Age } \\
\text { yrs. }\end{array}$ & $\begin{array}{l}\mathrm{BMl} \\
\mathrm{kg} / \mathrm{m}^{2}\end{array}$ & $\begin{array}{l}\text { Smoking index } \\
\text { p.y }\end{array}$ & $\mathrm{FEV}_{1} \%$ pred \\
\hline 1 & male & 48 & 22.5 & 30 & 60.3 \\
2 & male & 67 & 19.3 & 40 & 45.0 \\
3 & male & 54 & 26.3 & 80 & 33.8 \\
4 & male & 64 & 16.7 & 30 & 16.1 \\
5 & male & 56 & 25.9 & 30 & 34.8 \\
6 & male & 67 & 24.5 & 40 & 41.2 \\
7 & male & 70 & 22.3 & 25 & 33.3 \\
8 & male & 67 & 18.4 & 32 & 33.4 \\
9 & male & 75 & 26.0 & 25 & 43.1 \\
10 & male & 48 & 27.6 & 20 & 54.3 \\
\hline
\end{tabular}

$B M I$ body mass index, p.y pack-yrs, $F E V$, forced expiratory volume in $1 \mathrm{sec}$, \%pred \%predicted
rhBAFF or a combination of rhBAFF and BR3-Fc. The mRNA levels of perforin and granzyme $B$ in the cells were detected. We found that the mRNA levels of perforin and granzyme $\mathrm{B}$ in the $\mathrm{CD} 8^{+}$cells were both increased significantly after BAFF treatment (Fig. 6).

\section{Discussion}

BAFF has been extensively studied in autoimmune diseases such as systemic lupus erythematosus and rheumatoid arthritis [19]. Several studies have suggested that BAFF may be implicated in the pathogenesis of COPD including our previous research using mouse models [20], however its role in this chronic inflammatory disease is not fully understood. Considering that BAFF also regulates $\mathrm{T}$ cell function, in the present study, we mainly investigated its effect on $\mathrm{T}$ lymphocytes in COPD.

Using immunocytochemistry, we show that BAFF expression in the cells (mainly macrophages) of sputum from COPD patients is increased compared with smokers and nonsmokers, which is consistent with the findings of previous clinical studies [12, 13]. We also show that BAFF expression in the plasma is significantly increased in COPD patients compared with nonsmokers and smokers. Further analysis suggests that plasma BAFF levels are inversely correlated with $\mathrm{FEV}_{1}$ \%pred in patients with COPD. These results imply that BAFF may 

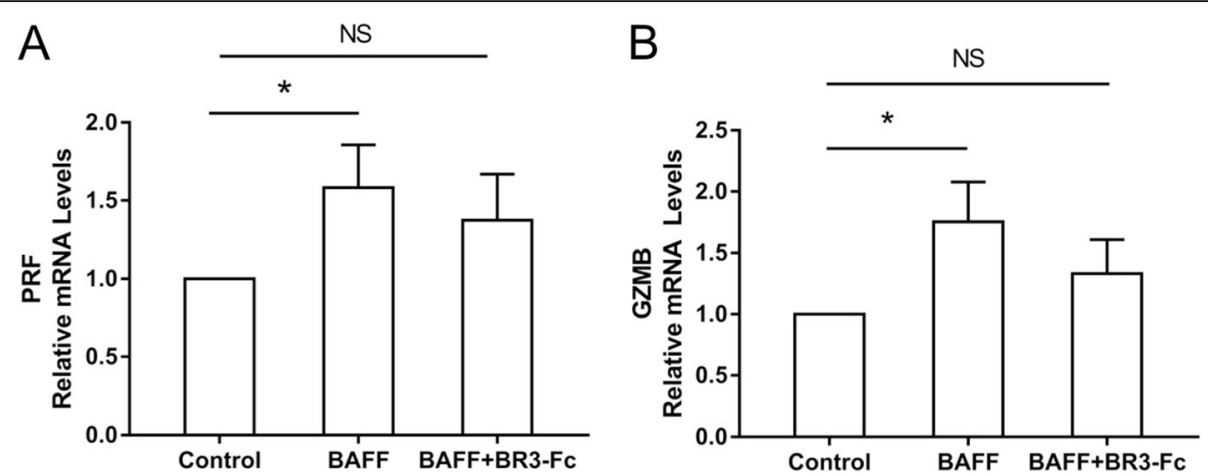

Fig. 6 Effects of B cell activating factor (BAFF) on perforin and granzyme B expression of CD8 ${ }^{+}$cells from COPD patients. CD $8^{+}$cells isolated from COPD patients were treated with control, recombinant human BAFF (rhBAFF) or rhBAFF plus BR3-Fc (BAFF antagonist) and the expression levels of perforin (PRF) and granzyme B (GZMB) were detected. The relative mRNA levels of PRF (a) and GZMB (b) in the CD $8^{+}$cells from COPD patients $(n=10)$ are shown. ${ }^{*} P<0.05$. NS, nonsignificant

play an important role in the inflammatory response in COPD and plasma BAFF may serve as a biomarker for disease severity.

The abnormal inflammatory response in the small airways and alveoli in COPD involves many inflammatory cells including neutrophils, macrophages and T lymphocytes [21]. T lymphocytes are increased in patients with COPD and the number of $\mathrm{T}$ lymphocytes $/ \mathrm{mm}^{3}$ of lung is correlated with the extent of emphysema [22]. Different $\mathrm{T}$ cell subsets have been identified in the pathogenesis of this disease including $\mathrm{CD}^{+}$and $\mathrm{CD}^{+}{ }^{+} \mathrm{T}$ cells, and the former predominates over the latter in the airways and lung parenchyma [23]. Previous studies have shown that there is a significant negative association between the $\mathrm{CD}^{+} \mathrm{T}$ cell subset and $\mathrm{FEV}_{1}$ percentage of predicted in the chronic bronchitic smokers [24]. Later studies also suggest that reduced apoptosis of $\mathrm{CD} 8^{+}$cells may contribute to the accumulation of these cells in the lung [5]. BAFF has been shown to promote the survival of $\mathrm{CD}^{+}$cells in immune thrombocytopenia patients [25], however the effect of BAFF on the apoptosis of T lymphocytes in COPD has not been studied yet. In the present study, we show that BAFF significantly inhibits the apoptosis of $\mathrm{CD}^{+}$cells in COPD, which might be one of the ways that BAFF participates in the pathogenesis of this disease. However we also show that BAFF does not significantly alter the apoptosis of $\mathrm{CD} 4^{+}$cells in COPD, suggesting that BAFF might have different effects on different $\mathrm{T}$ cell subsets.

Cytotoxic $\mathrm{CD}^{+} \mathrm{T}$ cells can induce apoptosis of target cells including bronchial epithelial cells through multiple mechanisms including the granzyme mediated pathway [26]. Granzyme B and perforin are stored in cytoplasmic secretory granules of these cytotoxic cells, and released into the intercellular space following adhesion to the target cell. Perforin forms transmembrane pores in the target cell, facilitating the entry of granzyme B and induction of apoptosis by activation of caspases [27]. It has been shown that the expression of granzyme $\mathrm{B}$ and perforin is increased in $\mathrm{T}$ cells from COPD patients $[28,29]$. In the present study, we show that the expression levels of perforin and granzyme $\mathrm{B}$ in the $\mathrm{CD}^{+}$cells from COPD patients are both increased significantly after BAFF stimulation, suggesting that BAFF may affect the granzyme/perforin mediated pathway in COPD. This might be another way that BAFF participates in the pathogenesis of this disease.

$\mathrm{CD} 4^{+} \mathrm{T}$ cells that accumulate in the airways and lungs of COPD patients mainly produce IFN- $\gamma$ and therefore have a Th1 phenotype [30]. Previous studies have suggested that intracellular Th1 proinflammatory cytokine production is increased in peripheral blood, bronchoalveolar lavage and intraepithelial $\mathrm{T}$ cells of COPD subjects, and the number of IFN- $\gamma$ positive lymphocytes is inversely correlated with $\mathrm{FEV}_{1}$ \%pred [31, 32]. It has been shown that there is an increased percentage of IFN- $\gamma$ producing cells and a decreased percentage of IL-4 producing cells among peripheral blood $\mathrm{CD} 4^{+} \mathrm{T}$ cells from the patients with COPD compared with control subjects [33]. In the present study, we show that the expression of IFN- $\gamma$ in the $\mathrm{CD}^{+}$cells from COPD patients is increased significantly after BAFF treatment, however BAFF does not significantly alter the expression of IL-4 in these cells. The results suggest that BAFF may augment Th1 associated inflammatory responses in COPD.

In summary, we report that BAFF expression is increased in the cells of sputum and the plasma from COPD patients and the plasma BAFF levels are inversely correlated with $\mathrm{FEV}_{1}$ \%pred in COPD; BAFF inhibits the apoptosis of $\mathrm{CD}^{+}$cells and increases the expression of perforin and granzyme B in these cells from COPD patients; BAFF increases IFN- $\gamma$ but not IL-4 expression in the $\mathrm{CD} 4^{+}$cells from COPD patients. Our findings indicate that BAFF may be involved in the inflammatory response in COPD via affecting $\mathrm{T}$ lymphocytes, suggesting a possible role of BAFF in the pathogenesis of COPD. 


\section{Abbreviations}

APC: Allophycocyanin; BAFF: B cell activating factor belonging to the tumor necrosis factor family; BCMA: B cell maturation antigen; BSA: Bovine serum albumin; COPD: Chronic obstructive pulmonary disease; ELISA: Enzyme-linked immunosorbent assay; $\mathrm{FEV}_{1}$ : Forced expiratory volume in one second FITC: Fluorescein isothiocyanate; FVC: Forced vital capacity; GOLD: Global Initiative for Chronic Obstructive Lung Disease; IFN- $\gamma$ : Interferon- $\gamma$; IL4: Interleukin 4; PBMC: Peripheral blood mononuclear cell; PBS: Phosphate buffered saline; PCR: Polymerase chain reaction; PE: Phycoerythrin; TACl: Transmembrane activator and calcium modulator cyclophilin ligand interactor

\section{Acknowledgements}

The authors would like to thank Fanqian Zeng and Chad Marion for editorial assistance.

\section{Authors' contributions}

SG recruited the subjects, performed the experiments and data analysis, and drafted the manuscript. JC participated in the experiments and data analysis. $J X$ recruited the subjects and participated in the experiments and data analysis. JW conceived of the study and its design, analyzed the data and revised the manuscript. All authors read and approved the final manuscript.

\section{Funding}

This work is supported by National Natural Science Foundation of China (NSFC) under the grant number 81200029 and 81670035

\section{Availability of data and materials}

Not applicable.

\section{Ethics approval and consent to participate}

This study was approved by the Institutional Review Board of Tongji Hospital, Tongji Medical College, Huazhong University of Science and Technology. Written informed consents were obtained from all participants.

\section{Consent for publication}

Not applicable.

\section{Competing interests}

The authors declare that they have no competing interests.

Received: 9 December 2019 Accepted: 6 March 2020

Published online: 11 March 2020

\section{References}

1. Vogelmeier CF, Criner GJ, Martinez FJ, Anzueto A, Barnes PJ, Bourbeau J, Celli BR, Chen R, Decramer M, Fabbri LM, Frith P, Halpin DM, López Varela MV, Nishimura M, Roche N, Rodriguez-Roisin R, Sin DD, Singh D, Stockley R, Vestbo J, Wedzicha JA, Agustí A. Global strategy for the diagnosis, management, and prevention of chronic obstructive lung disease 2017 report. GOLD executive summary. Am J Respir Crit Care Med. 2017;195:557-82.

2. Mathers CD, Loncar D. Projections of global mortality and burden of disease from 2002 to 2030. PLoS Med. 2006;3:e442.

3. Barnes PJ. Inflammatory mechanisms in patients with chronic obstructive pulmonary disease. J Allergy Clin Immunol. 2016;138:16-27.

4. Hogg JC, Timens W. The pathology of chronic obstructive pulmonary disease. Annu Rev Pathol. 2009:4:435-59.

5. Siena L, Gjomarkaj M, Elliot J, Pace E, Bruno A, Baraldo S, Saetta M, Bonsignore MR, James A. Reduced apoptosis of CD8+ T-lymphocytes in the airways of smokers with mild/moderate COPD. Respir Med. 2011;105:1491-500.

6. Urbanowicz RA, Lamb JR, Todd I, Corne JM, Fairclough LC. Enhanced effector function of cytotoxic cells in the induced sputum of COPD patients. Respir Res. 2010;11:76.

7. Grumelli S, Corry DB, Song LZ, Song L, Green L, Huh J, Hacken J, Espada R, Bag $R$, Lewis DE, Kheradmand F. An immune basis for lung parenchymal destruction in chronic obstructive pulmonary disease and emphysema. PLoS Med. 2004;1:e8.

8. Schiemann B, Gommerman JL, Vora K, Cachero TG, Shulga-Morskaya S, Dobles M, Frew E, Scott ML. An essential role for BAFF in the normal development of B cells through a BCMA-independent pathway. Science. 2001;293:2111-4
9. Kalled SL. Impact of the BAFF/BR3 axis on B cell survival, germinal center maintenance and antibody production. Semin Immunol. 2006:18:290-6.

10. Moisini I, Davidson A. BAFF: a local and systemic target in autoimmune diseases. Clin Exp Immunol. 2009;158:155-63.

11. Scapini $P$, Hu Y, Chu CL, Migone TS, Defranco AL, Cassatella MA, Lowell CA. Myeloid cells, BAFF, and IFN-gamma establish an inflammatory loop that exacerbates autoimmunity in Lyn-deficient mice. J Exp Med. 2010;207:1757-73.

12. Polverino F, Baraldo S, Bazzan E, Agostini S, Turato G, Lunardi F, Balestro E, Damin M, Papi A, Maestrelli P, Calabrese F, Saetta M. A novel insight into adaptive immunity in chronic obstructive pulmonary disease: B cell activating factor belonging to the tumor necrosis factor family. Am J Respir Crit Care Med. 2010;182:1011-9.

13. Polverino F, Cosio BG, Pons J, Laucho-Contreras M, Tejera P, Iglesias A, Rios A, Jahn A, Sauleda J, Divo M, Pinto-Plata V, Sholl L, Rosas 1O, Agustí A, Celli BR, Owen CA. B cell-activating factor. An orchestrator of lymphoid follicles in severe chronic obstructive pulmonary disease. Am J Respir Crit Care Med. 2015:192:695-705.

14. Seys LJ, Verhamme FM, Schinwald A, Hammad H, Cunoosamy DM, Bantsimba-Malanda C, Sabirsh A, McCall E, Flavell L, Herbst R, Provoost S, Lambrecht BN, Joos GF, Brusselle GG, Bracke KR. Role of B cell-activating factor in chronic obstructive pulmonary disease. Am J Respir Crit Care Med. 2015;192:706-18.

15. Huard B, Arlettaz L, Ambrose C, Kindler V, Mauri D, Roosnek E, Tschopp J, Schneider $\mathrm{P}$, French LE. BAFF production by antigen-presenting cells provides T cell co-stimulation. Int Immunol. 2004;16:467-75.

16. Sutherland AP, Ng LG, Fletcher CA, Shum B, Newton RA, Grey ST, Rolph MS, Mackay F, Mackay CR. BAFF augments certain Th1-associated inflammatory responses. J Immunol. 2005:174:5537-44.

17. Pellegrino R, Viegi G, Brusasco V, Crapo RO, Burgos F, Casaburi R, Coates A, van der Grinten CP, Gustafsson P, Hankinson J, Jensen R, Johnson DC, Maclntyre N, McKay R, Miller MR, Navajas D, Pedersen OF, Wanger J. Interpretative strategies for lung function tests. Eur Respir J. 2005;26:948-68.

18. Rutgers SR, Timens W, Kaufmann HF, van der Mark TW, Koëter GH, Postma DS. Comparison of induced sputum with bronchial wash, bronchoalveolar lavage and bronchial biopsies in COPD. Eur Respir J. 2000;15:109-15.

19. Davidson A. Targeting BAFF in autoimmunity. Curr Opin Immunol. 2010;22:732-9.

20. Wang J, Li Q, Xie J, Xu Y. Cigarette smoke inhibits BAFF expression and mucosal immunoglobulin a responses in the lung during influenza virus infection. Respir Res. 2015;16:37.

21. Hogg JC, Chu F, Utokaparch S, Woods R, Elliott WM, Buzatu L, Cherniack RM, Rogers RM, Sciurba FC, Coxson HO, Paré PD. The nature of small-airway obstruction in chronic obstructive pulmonary disease. N Engl J Med. 2004; 350:2645-53.

22. Finkelstein R, Fraser RS, Ghezzo H, Cosio MG. Alveolar inflammation and its relation to emphysema in smokers. Am J Respir Crit Care Med. 1995;152:1666-72.

23. Saetta M, Di Stefano A, Turato G, Facchini FM, Corbino L, Mapp CE, Maestrelli P, Ciaccia A, Fabbri LM. CD8+ T-lymphocytes in peripheral airways of smokers with chronic obstructive pulmonary disease. Am J Respir Crit Care Med. 1998:157:822-6.

24. O'Shaughnessy TC, Ansari TW, Barnes NC, Jeffery PK. Inflammation in bronchial biopsies of subjects with chronic bronchitis: inverse relationship of CD8+ T lymphocytes with FEV1. Am J Respir Crit Care Med. 1997;155:852-7.

25. Zhu XJ, Shi Y, Peng J, Guo CS, Shan NN, Qin P, Ji XB, Hou M. The effects of BAFF and BAFF-R-fC fusion protein in immune thrombocytopenia. Blood. 2009;114:5362-7.

26. Shen DT, Ma JS, Mather J, Vukmanovic S, Radoja S. Activation of primary T lymphocytes results in lysosome development and polarized granule exocytosis in CD4+ and CD8+ subsets, whereas expression of lytic molecules confers cytotoxicity to CD8+ T cells. J Leukoc Biol. 2006;80:827-37.

27. Darmon AJ, Nicholson DW, Bleackley RC. Activation of the apoptotic protease CPP32 by cytotoxic T-cell-derived granzyme B. Nature. 1995;377:446-8.

28. Hodge S, Hodge G, Nairn J, Holmes M, Reynolds PN. Increased airway granzyme $b$ and perforin in current and ex-smoking COPD subjects. COPD. 2006:3:179-87.

29. Kim WD, Chi HS, Choe KH, Oh YM, Lee SD, Kim KR, Yoo KH, Ngan DA, Elliott WM, Granville DJ, Sin DD, Hogg JC. A possible role for CD8+ and non-CD8+ cell granzyme B in early small airway wall remodelling in centrilobular emphysema. Respirology. 2013;18:688-96.

30. Curtis JL, Freeman CM, Hogg JC. The immunopathogenesis of chronic obstructive pulmonary disease: insights from recent research. Proc Am Thorac Soc. 2007:4:512-21. 
31. Hodge G, Nairn J, Holmes M, Reynolds PN, Hodge S. Increased intracellular Thelper 1 proinflammatory cytokine production in peripheral blood, bronchoalveolar lavage and intraepithelial T cells of COPD subjects. Clin Exp Immunol. 2007;150:22-9.

32. Di Stefano A, Caramori G, Capelli A, Gnemmi I, Ricciardolo FL, Oates T, Donner CF, Chung KF, Barnes PJ, Adcock IM. STAT4 activation in smokers and patients with chronic obstructive pulmonary disease. Eur Respir J. 2004;24:78-85.

33. Majori M, Corradi M, Caminati A, Cacciani G, Bertacco S, Pesci A. Predominant TH1 cytokine pattern in peripheral blood from subjects with chronic

obstructive pulmonary disease. J Allergy Clin Immunol. 1999;103:458-62.

\section{Publisher's Note}

Springer Nature remains neutral with regard to jurisdictional claims in published maps and institutional affiliations.

Ready to submit your research? Choose BMC and benefit from:

- fast, convenient online submission

- thorough peer review by experienced researchers in your field

- rapid publication on acceptance

- support for research data, including large and complex data types

- gold Open Access which fosters wider collaboration and increased citations

- maximum visibility for your research: over $100 \mathrm{M}$ website views per year

At BMC, research is always in progress.

Learn more biomedcentral.com/submissions 